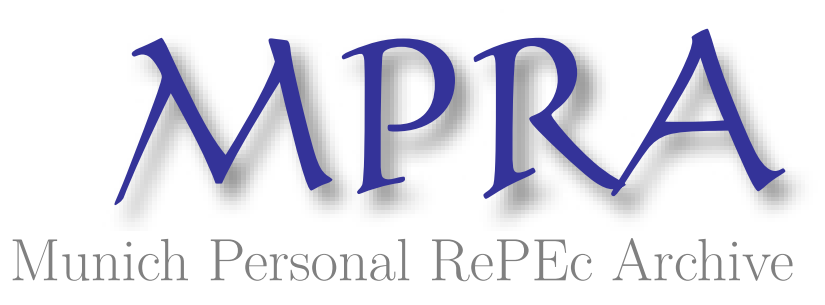

\title{
A Simple Index of Banking Fragility: Application to Indian Data
}

Saibal, Ghosh

2010

Online at https://mpra.ub.uni-muenchen.de/30321/

MPRA Paper No. 30321, posted 15 Apr 2011 14:48 UTC 


\title{
A Simple Index of Banking Fragility: Application to Indian Data
}

\author{
SAIBAL GHOSH
}

\begin{abstract}
Using data on Indian banks for 1997-2007, the paper develops an index of banking fragility and subsequently examines the factors affecting the index. Based on the statistical properties of the index, we classify banks as exhibiting high, moderate and low stability. The multivariate regressions indicate an important role for banking industry variables in influencing the index.
\end{abstract}

JEL Classification: G 21, G 28, P 52

Key words: Banking stability index; state-owned banks; foreign banks; India

\section{Introduction}

The outbreak of the subprime episode has spawned a growing literature on the reasons for the causes of the meltdown. The reasons behind the crisis have been well-documented (Blanchard, 2008; Dodd and Mills, 2008; Mishkin, 2008). Since banks were at the epicenter of the crisis, attempts have been underway to explore how best to build a strong and robust banking system.

Such attempts are obviously not new. In the wake of the Asian crisis a decade ago and even more recently, during the banking crises in Argentina and Turkey, policymakers have been making proactive efforts to restructure their banking systems (Hoelscher and Ingves, 2006). The idea behind such strategies has been to nurture the banking system back to a position of profitability and solvency using private sector solutions and public sector assisted resolutions, or combinations thereof.

Research on these aspects has veered in two broad directions. A first strand of the literature focuses on leading indicator models of banking sector problems. Under this signaling version of this approach, indicators are chosen on whether changes in their behavior between normal times and during times of stress provide reliable 'signal' of a crisis (Kaminsky and Reinhart, 1999). ${ }^{1}$ The alternate line of thinking - the qualitative response models - employs regression techniques between the various potential indicators and identified discrete outcomes such as a bank failure or a banking crisis. Micro versions of this framework (Gonzalez-Hermosillo, 1999) focus on individual bank's balance sheet data, to forecast failure of individual institutions. The more encompassing macro version apply judgments to date banking crisis based on certain quantifiable criteria and attempt to identify the set of macroeconomic, banking sector and institutional factors that are influential in identifying banking crises

${ }_{1}^{1}$ The threshold value of the chosen indicator attempts to strike a balance between having many false alarms (type II error) and the risk of missing many crises (type I error).

pg. 1 
(Demirguc-Kunt and Detragiache, 1999). Although the list of indicators found important in 'explaining' crisis varies across studies (Hardy and Pazarbasioglu, 1998; Hutchinson and McDill, 1999; Eichengreen and Arteta, 2000), certain results appear to be robust. In particular, rapid domestic credit expansion, large bank liabilities relative to reserves and domestic financial liberalization all appear to be important in generating systemic banking crises. This suggests that banking systems are most at risk when deregulation and economic liberalization combine to create an unsustainable lending boom (Eichengreen and Arteta, 2000).

Another strand of the literature has been to develop indicators of banking stability, instead of examining factors affecting them. Work in this area is evolving (CNB, 2007). A recent attempt by Segoviano and Goodhart (hereafter, SG, 2009) develops a banking stability index (BSI), based on the banks' joint probability of default (JPoD). Based on the JPoD, a BSI can be constructed, which reflects the expected number of bank defaults, given that at least one bank defaults, higher numbers signify greater instability.

The present paper also develops a BSI, but in contrast to the approach of SG (2009), takes a different track. More specifically, it develops a bank-wise stability index taking on board several important aspects of banking operations and thereafter examines which sets of factors are influential in impacting this index. Although less sophisticated than the SG index, it has the advantage of placing minimal restrictions on the data and is computationally less burdensome. As well, it can be easily tailored to country requirements by suitably modifying the set of relevant variables under its domain.

\section{Banking Stability Index (BSI): Methodology and Construction}

For the analysis, we use annual data on state-owned banks for 1997-2007. We selected this time period for two main reasons. First, it seems sufficiently long to allow long-run influences, which have a bearing on bank functioning, to play out. Second, the period coincides with the availability of consistent data on all the bank-level variables of interest. As such, notwithstanding the growing footprints of private and foreign banks in the Indian banking marketplace, state-owned banks still dominate the system, accounting for, on average, nearly three-quarter of banking sector assets (See, for instance, Chairlone and Ghosh, 2009 for an overview). There are presently 28 state-owned banks, of which four are among the top five (in terms of assets) in the banking space. In tandem with the greater liberalization of the economy, the banking system has become increasingly competitive. Banks have also broad-based their capital base through a process of equity privatization (Bourbakri et al., 2005) with attendant improvements in shareholder value (Reddy, 2002).

pg. 2 
The data for the analysis are drawn from Statistical tables relating to banks in India, a yearly publication that reports balance sheet figures and profit and loss numbers at the bank-level. The prudential ratios for banks are culled out from Report on trend and progress of banking in India, a statutory publication that provides bank-level prudential and financial ratios. Taken together, these two publications account for all of the bank-level variables employed in the analysis. The macro variables for the study come from the Handbook of statistics on Indian economy, another yearly publication that provides time series data on monetary and macro variables.

We utilize the following three indicators of banking operations:

(a) Loan loss provisions to total asset ratio

(b) Total capital to total risk weighted asset ratio, or capital adequacy ratio (CAR)

(c) Profitability (RoA), measured as profit after tax to total asset ratio

These indicators take on board the three major dimensions of banking operations: stability, soundness and profitability. While the use of RoA as a measure of bank profitability is quite commonplace in the literature, these use of the other two indicators as measures of bank stability and soundness are also much in vogue (Martinez Peria and Schmukler, 2001; Demirguc Kunt and Huizinga, 2004).

To construct the BSI, we proceed as follows. For any indicator $i$, the index for the $i$ th dimension, $d_{i}$, is given by the expression:

$d_{i}=\frac{A_{i}-m_{i}}{M_{i}-m_{i}}$

where $A$ is the actual, $M$ and $m$ are the maximum and minimum value of dimension $i{ }^{2}$ Clearly, higher values of $d_{i}$ would suggest higher levels of achievement by the bank in dimension $i$. In the $n$ dimensional space, the index is given by (2) according as:

$B S I_{j}=1-\frac{\sqrt{\sum_{i=1}^{n}\left(1-d_{i}\right)^{2}}}{\sqrt{n}}$

In other words, BSI is the normalized inverse Euclidean distance of the actual point from the ideal point (which is 1 , that represents the highest achievement in all dimensions). ${ }^{3}$ Given that the minimum and maximum values are likely to be time-varying in nature, the $B S I$ index has the flexibility to

[) Note that, from (1), $0 \leq d_{i} \leq 1$

${ }^{3}$ The normalization in the denominator in (2) is made in order to make the value lie between 0 and 1. 
appropriately take this aspect into account. It, therefore, allows for comparison of the extent of stability of a bank over time as also relative to other banks. Judged thus, the index is both dynamic and flexible.

Table 1 presents the summary statistics of the BSI and the other relevant variables employed in the study. The BSI has an average of 0.49 (median of 0.51), suggesting moderate levels of stability for the average bank. The fact that the median is higher than mean indicates a negatively skewed distribution. The top and bottom 10 percentile values of the index are 0.63 and 0.30 , respectively. Based on these percentile numbers, we classify banks as exhibiting high stability if the BSI exceeds the value at 90 percentile. Likewise, banks are classified as exhibiting moderate and low stability if the BSI lies between the median and 90 percentile, or are below the median, respectively.

Table 1. Bank-specific variables - description and summary statistics

\begin{tabular}{|c|c|c|c|c|c|c|}
\hline Variable & Definition & Obs. & Mean & Std. dev. & Minimum & Maximum \\
\hline $\mathrm{BSI}$ & Index of banking stability & 307 & 0.487 & 0.249 & 0.144 & 0.908 \\
\hline SIZE & Log (total asset) & 308 & 10.221 & 0.947 & 6.670 & 13.250 \\
\hline $\mathrm{CIR}$ & $\begin{array}{l}\text { Cost income ratio (=Operating expense/(Total income - interest } \\
\text { expense) }\end{array}$ & 308 & 0.582 & 0.165 & 0.300 & 1.680 \\
\hline Gr_Credit & Change in logarithm of real loan growth & 308 & 0.195 & 0.504 & -0.200 & 7.311 \\
\hline Gr_Branch & Change in logarithm of branch growth & 308 & 0.033 & 0.117 & -0.050 & 1.253 \\
\hline dy_Merger & Dummy $=1$ for the acquirer in the year of merger, else zero & 308 & 0.036 & 0.186 & 0 & 1 \\
\hline dy_Reg & Dummy=1 for the years beginning 2004 , else zero & & & & & \\
\hline Concentration & Herfindahl index of bank credit & 308 & 0.064 & 0.007 & 0.054 & 0.074 \\
\hline Foreign & Fraction of banking system assets that are foreign-owned & 308 & 0.074 & 0.005 & 0.065 & 0.082 \\
\hline dy_GDPGR & $\begin{array}{l}\text { Dummy=1 if real GDP growth exceeds the sample median, else } \\
\text { zero }\end{array}$ & 308 & 0.545 & 0.498 & 0 & 0 \\
\hline dy_Rol & $\begin{array}{l}\text { Dummy=1 if real interest rate growth exceeds the sample } \\
\text { median, else zero. The real interest rate is computed as: } \\
{[(1+\text { Lending Rate }) /(1+W P I \text { Inflation })]-1}\end{array}$ & 308 & 0.545 & 0.498 & 1 & 1 \\
\hline Divest & Fraction of equity divested by the government & 308 & 0.168 & 0.176 & 0 & 0.490 \\
\hline
\end{tabular}

\section{Empirical strategy and results}

To estimate the impact of factors affecting the BSI, we employ regressions of the following form:

$$
\log \left[\left(B S I_{s t}\right) /\left(1-B S I_{s t}\right)\right]=\varphi_{0}+\varphi_{1} B_{s t}+\varphi_{2} Z_{t}+\varphi_{3} M_{t}+\varepsilon_{s t}
$$

where $s$ indexes bank and $t$ denotes year; $\varphi s^{\prime}$ are the parameters to be estimated.

The dependent variable is the BSI described earlier. Since the index lies in the unit interval and does not assume extreme values, we make a log transformation as in LHS of (3). The range of the new dependent variable is $[-\infty,+\infty]$.

In (3), the dependent variable is assumed to be a function of bank-level controls $(B)$, timevarying banking industry specific variables $(Z)$, including measures of concentration and asset share of foreign banks and macroeconomic controls $(M)$, such as real GDP growth and real interest rate. To moderate the influence of noise, instead of the continuous variables, we employ dummies in their place. Finally, bank-specific dummies (BD) are included to control for bank-specific effects, but not reported. 
The vector of bank-level controls includes bank size, cost income ratio, the real credit growth and branch expansion. To the extent bank size acts as a proxy for diversification, it seems likely that bigger banks could exhibit higher stability. Both higher credit extension and greater branch expansion could entail higher risk owing to adverse selection problems, suggesting an expected negative sign on these variables. Among banking industry controls, we include a dummy for regulation, coinciding with the tightening of prudential regulations for loan classification beginning 2004 and control for the effect of bank mergers.

We have observations on 28 banks for the period 1997-2007, yielding a maximum of 308 bankyears. Column (1) of Table 3 presents the baseline regression results. Among bank-level variables, the coefficient on branch expansion is positive, suggesting that banks with aggressive branch expansion strategies are relatively more stable. Greater branch expansion presumably allows for better risk diversification, with a salutary impact on BSI. The coefficients suggest small effects: a $10 \%$ rise in branch expansion raises banking stability by roughly $1.6 \%$. Among the banking industry variables, it is observed that a tightening of prudential regulations is associated with a decline in the index value.

All models take on board the impact of the business cycle and the interest rate. Across all specifications, these are significant and have expected signs. Thus, a rise in GDP growth and a decline in real interest rate appears to lower banking fragility.

Table 3. Banking Stability Index: Regression results

\begin{tabular}{lcccc}
\hline Variable & $(1)$ & $(4)$ & $(3)$ & $(2)$ \\
\hline Constant & $1.051(0.853)$ & $1.052(0.847)$ & $0.423(0.809)$ & $-2.652(0.563)^{* * *}$ \\
Size & $-0.093(0.075)$ & $-0.093(0.076)$ & $-0.086(0.073)$ & $-0.147(0.039)^{* * *}$ \\
CIR & $-0.172(0.293)$ & $-0.173(0.305)$ & $-0.294(0.290)$ & $-0.272(0.265)$ \\
Gr_Credit & $-0.006(0.009)$ & $-0.006(0.009)$ & $0.020(0.015)$ & $0.006(0.008)$ \\
Gr_Branch & $0.163(0.069)^{* *}$ & $0.163(0.069)^{* *}$ & $0.064(0.096)$ & $0.279(0.074)^{* * *}$ \\
dy_REG & $-0.148(0.064)^{* *}$ & $-0.148(0.066)^{* *}$ & $-0.164(0.063)^{* * *}$ & $-0.165(0.055)^{* * *}$ \\
dy_Merger & $0.130(0.083)$ & $0.131(0.083)$ & $0.142(0.073)^{*}$ & $0.034(0.050)$ \\
dy_GDPGR & $0.043(0.024)^{*}$ & $0.043(0.025)^{*}$ & $0.066(0.026)^{* * *}$ & $0.050(0.025)^{* *}$ \\
dy_Rol & $-0.056(0.023)^{* *}$ & $-0.056(0.024)^{* *}$ & $-0.054(0.023)^{* *}$ & $-0.028(0.020)$ \\
PGO & & $0.002(0.173)$ & & $0.842(0.309)^{* * *}$ \\
Foreign & & & & $0.238(0.043)^{* * *}$ \\
Concentration & & & YES & YES \\
Bank controls & YES & YES & 28,307 & 28,307 \\
Banks, N.Obs & 28,307 & 28,307 & 0.391 & 0.447 \\
R-squared & 0.364 & 0.364 & & \\
\hline Strandard & & &
\end{tabular}

Standard errors (clustered by bank) are within brackets

$* * *, * *$ and $*$ denote statistical significance at the 1,5 and $10 \%$, respectively

The second model includes an additional bank-specific variable: the fraction of equity divested in the bank (Divest). If divestment is associated with improvements in market discipline and thereby greater banking stability, the coefficient on this variable should be positive. In Col. (2), the coefficient on Divest is not significant, suggesting that there is not any significant difference in stability between listed versus unlisted banks. 
Specifications (3)-(4) includes indicators of the market structure of banking systems. Specifically, the variable Foreign denote the fraction of banking sector assets that are owned by foreign banks, while Concentration is defined as the Herfindahl index of bank credit.

The coefficient on Foreign is positive and statistically significant. In economic terms, everything else equal, greater foreign bank presence appears to lead to an improvement in banking stability. The magnitudes are economically important as well: a rise in foreign bank presence by $1 \%$ raises banking stability by roughly $0.8 \%$. Given the average share of foreign banks is $7.4 \%$, therefore, an increase to rise to $8.1 \%$ (a $10 \%$ rise) would raise the average value of $\mathrm{BSI}$ to 0.53 .

In specification (4), the coefficient on concentration is positive and statistically significant as well. This suggests that greater concentration leads to an improvement in banking stability. The magnitudes, although significant, are much lower as compared to Foreign: a $10 \%$ rise in credit concentration raises banking stability by roughly $2.4 \%$.

\section{Policy concerns}

Using data on Indian state-owned banks for 1997-2007, the paper employs three major dimensions of banking operations to construct an index of banking stability. Based on the index so constructed, we classify banks as exhibiting low, moderate and high stability.

The regression results indicate that it is primarily banking industry variables that appear to impact banking stability. More specifically, the findings suggest an important role for prudential norms, concentration and foreign bank presence in influencing this index. These factors call into question certain conventional wisdom. For one, policymakers have often resisted greater foreign bank presence in their economies for fear of 'cherry picking'. The evidence presented suggests that, on the contrary, by improving overall competition, foreign banks can actually lead to an improvement in banking stability. As well, greater concentration is often believed to be at odds with a competitive banking system. Here again, the evidence supports the fact that concentration could actually increase banking stability. This assumes relevance in view of the spate of mergers and amalgamations engulfing the industry at the present juncture. Finally, the analysis suggests an important role for regulation in banking stability, so much so that policymakers need to appropriately take on board the trade-off between convergence to international best practices and ensuring a sound banking system.

\section{References}


Blanchard, O. (2008), "Cracks in the system: Repairing the damaged global economy", Finance and Development (December). 8-10,. IMF: Washington DC.

Chairlone, S., and Ghosh, S. (2009), "Indian banking system", In P. Bongini, S. Chairlone and G. Ferri (Eds.) Emerging Banking Systems. Palgrave McMillan: UK.

CNB (2007), "Financial stability indicators : Advantages and disadvantages of their use in the assessment of financial system stability", Czech National Bank: Prague.

Demirguc Kunt, A., and Detragiache, E. (1998b), "The determinants of banking crises in developing and developed countries", IMF Staff Papers 45, 2, 119-41.

Demirguc Kunt, A., and Huizinga, H. (2004), "Market discipline and financial safety net design", Journal of Monetary Economics 51, 3, 375-99.

Dodd, R., and Mills, P. (2008), “Outbreak: U.S. subprime contagion”, Finance and Development (June). 1-18. IMF: Washington DC.

Eichengreen, B., and Arteta, C. (2000), "Banking crises in emerging markets: Presumptions and evidence", Center for International Development Economics Research Working Paper No. 115. Haas School of Business, University of California Berkeley.

Gonzalez-Hermosillo, B. (1999), "Determinants of ex ante banking system distress: A macro micro exploration of some recent episodes", IMF Staff Papers No. 33, 2, 119-34.

Hardy, D., and Pazarbasioglu, C. (1998), “Leading indicators of banking crises: Was Asia different?”, IMF Working Paper No. 91. IMF: Washington DC.

Hoelscher, D. S. and Ingves, S. (2006), "The resolution of systemic banking system crises", In D.S.Hoelscher (Ed.) Bank Restructuring and Resolution. IMF: Washington DC, pp. 3-22.

Hutchinson, M., and McDill, K. (1999), "Are all banking crises alike? The Japanese experience in international comparison", NBER Working Paper No. 7253. Cambridge: MA.

Kaminsky, G., and Reinhart, C. (1999), "The twin crises: The causes of banking and balance of payments problems", American Economic Review 89, 2, 473-501.

Martinez-Peria, M.S. and Schmukler, S. (2001), "Do depositors punish banks for bad behavior: Market discipline, deposit insurance and banking crises', Journal of Finance 56, 3, 1029-51.

Mishkin, F.S. (2008), "Global financial turmoil and the world economy”, Address delivered at the Carsarea Forum, Israel, July 2. Available at <www.federalreserve. gov>

Reddy, Y.V. (2002), "Public sector banks and the governance challenge", Available at <www.bis.org/review/ r020422d.pdf>

Reserve Bank of India (2008), Handbook of Statistics on Indian Economy. RBI: Mumbai.

Reserve Bank of India, Report on Trend and Progress of Banking in India (various years). RBI: Mumbai.

Segoviano, M.A., and Goodhart, C.A.E. (2009), "Banking stability measures", IMF Working Paper No. 4. IMF: Washington DC. 